\title{
Innovation and supply chain orientation concerns toward job creation law in micro, small, and medium enterprises export-oriented products
}

\author{
Endang Purwaningsih ${ }^{a^{*}}$, Muslikh $^{\mathrm{b}}$ and Suhaeri ${ }^{\mathrm{c}}$
}

${ }^{a}$ Lecturer of Law Faculty, University of YARSI, Indonesia

${ }^{b}$ Lecturer of Economic Faculty, University of YARSI, Indonesia

${ }^{c}$ Lecturer of Technology Information Faculty, Universityof YARSI, Indonesia

A B S T R A C T

\begin{tabular}{l}
\hline Article history: \\
Received July 17, 2021 \\
Received in revised format \\
September 22, 2021 \\
Accepted October 192021 \\
Available online \\
October 192021 \\
\hline Keywords: \\
Supply chain orientation \\
Innovation \\
IPR \\
Branding \\
Job creation law \\
Export-oriented
\end{tabular}

\begin{abstract}
The supply chain of MSME products in the context of export penetration is very important, but MSME actors have not been able to meet all export needs. This study aims to: 1) analyze the supply chain of MSMEs in the context of export penetration in the era of the covid-19 pandemic, and 2) examine the potential of MSMEs to develop in terms of corporate legality, industrial design, and brand registration, as well as the use of digital marketing. This research method was quantitative research with survey approach and normative empirical study. The population of this study was 134 MSMEs, samples from 63 MSMEs in Central Java (Brebes), West Java (Bogor), and the Special Region of Yogyakarta (Bantul). Quantitative data analysis used Structural Equation Modeling (SEM) approach and analyzed with Smart PLS 3.3 software. The results of the study show: 1) the supply chain needs of MSMEs in penetrating the export market in the era of the covid19 pandemic are very difficult; 2) MSMEs must be able to meet all export needs to create a balanced supply chain, 3) in order to prepare export-oriented MSMEs, they must first motivate and educate, establish policies that support their legality and export management.
\end{abstract}

\section{Introduction}

This research is motivated by supply chain disruptions and the depletion of the supply of MSMEs products that are eligible for export, both in a series of high and low resources that have connected MSMEs products with the needs of the community from the destination country (environment, materials, and equipment). MSMEs actors are required to increase the capacity and quality of standardized products. Serious efforts are needed for MSMEs actors, the government as a companion, universities as partners, as well as improving communication and coordination as well as implementation strategies (Baltimoe, 2019). Procurement and supply chain management should also be improved to ensure adequate stock of essential flagship MSMEs products and to allow equitable access. The occurrence of the COVID-19 pandemic has led to an inadequate supply of raw materials for MSMEs products, and this shortage can have devastating consequences for product fulfillment (Hopman, Allegranzi, \& Mehtar, 2020). In this case, the government must provide clear guidance and act quickly to secure adequate supplies and stocks. Therefore, good supply chain management of MSMEs products is needed in order to grow the export market. Previous research that discusses supply chain management issues and has not touched in depth the obstacles and innovation models that can be done to deal with MSMEs problems in the midst of the Covid-19 pandemic. This study seeks to reveal these goals, namely, to innovate models and explain the obstacles experienced by Indonesian MSMEs actors today. Indonesia has millions of micros, small, and medium enterprises (MSMEs), but most of those that have been studied produce traditional and ready-to-eat foods and beverages, as well as herbs, so they have been largely unaffected by the COVID-19 pandemic. Other MSMEs have adapted by changing their production from non-food items to ready-to-consume food and beverages with the help of an association of MSME organizations. However, some SMEs lack knowledge and * Corresponding author

E-mail address: endangpyarsi@gmail.com (E. Purwaningsih)

(C) 2022 Growing Science Ltd. All rights reserved.

doi: $10.5267 /$ j.uscm.2021.10.009 
motivation in terms of a poor mindset or lack of competitive awareness; inadequate production factors; and a lack of legal knowledge, especially for contract law, trademark and legal entities, conventional marketing, branding, and e-commerce. In line with Indonesian Law Number 20 of 2008 concerning Micro, Small, and Medium Enterprises, MSMEs are separated into micro, small, and medium enterprises. In its development, the Omnibus Law on Job Creation number 11 of 2020 made provisions for (1) online single submission for medium and small enterprises (MSEs) through registration, (2) the facilitation of halal certificates at the government's expense, (3) government-provided incentives and conveniences for SMEs to partner with medium and large enterprises, (4) the synergistic integrated management of MSEs with stakeholders, (5) financing for further developing MSMEs, (6) priority government use of special allocation funds (DAK) to fund MSMEs' development activities, (7) legal assistance and IP protection services for MSEs, (8) prioritization of MSEs in government procurement of goods and services, and (9) MSE partnerships by providing promotional places, places of business, or MSE development of public infrastructure (30\% allocation). Observing the study of Irawan (2017) that was related to regulations, Marlinah (2020) stated, "The strength and independence of UMKN as capital in competition in the free market post-covid-19 pandemic implies a need for government support if MSMEs are to immediately rise."

Research phase 1 (2021) added some observations about the impact of the pandemic on MSMEs, such as whether they were able to survive and improve their ability to overcome various obstacles and what their level of knowledge was about legal processes like halal certification and trademark registration, as well as their level of motivation for becoming export-oriented companies. The goal is to raise the technological and economical knowledge of MSMEs, so they can improve local products through science and technology and be able to compete in the global market with good product branding, digitalization support, trademark ownership, and innovation. Based on this, an empowerment model was developed for application in the second year. As it is known that the supply chain network can be understood as a significant model in reducing costs incurred by supply chain links but can improve the quality of service that is able to bring goods and services closer to consumers. Strategies that can be used by MSMEs actors, government agencies that handle exports, assistants, universities, and all parties involved must be able to provide the best way so that the supply chain risk (SCR) of implementing MSMEs product exports can be resolved properly. Ivanov's latest research (2020) concluded that the closure of facilities at various levels due to the speed of the epidemic spread, had affected the supply chain from upstream to downstream. An approach is needed that can help identify and mitigate the risks of export activities in the new normal era. Miraz et al. (2019) explained that the supply chain in the pandemic era is detrimental to all parties, including MSMEs products that should be able to penetrate exports. Socio-economic, environmental, political, and institutional systems are needed that can support emergency management efforts (Lee, et al, 2020). This is in line with research conducted by Kozlenkova (2015) which states that Supply Chain Management (SCM) is used to show the need for the integration process from end use to original suppliers. Ji et al. (2020) also reveal that the relationship between resources and the ability to penetrate exports is closely related.

\section{Methodology}

\section{Research Design}

This research method is quantitative research with a survey approach. However, for data related to business law, the approach used is a normative empirical study applied to a participatory research approach.

\section{Population and Sample}

The population of this study is 134 MSMEs, a sample of 63 micro, small, and medium enterprises (MSMEs) in Indonesia, specifically in Central Java (Brebes), West Java (Bogor), and the Special Region of Yogyakarta (Bantul).

\section{Data Collection}

Data were collected using a questionnaire given to 63 SMEs. Qualitative data is supported by in-depth interviews and participatory research, statute, sociological, and historical approaches, such that data is obtained both from the literature and a questionnaire distributed to MSME producers in Bantul in Yogyakarta, Brebes in Central Java, and Bogor in WestJava. The research sample comprised MSMEs producers with headquarters in the above-mentioned areas. The research data comprised both primary and secondary data. The former was gathered through interviews, questionnaire distribution, and participatory observation. The latter, meanwhile, comprised both primary and secondary legal materials. To improve the accuracy of the primary data, structured interview guidelines and questionnaires were employed.

\section{Data Analysis}

Quantitative data analysis using Structural Equation Modelling (SEM) approach and analyzed by software Smart PLS 3.0. With this analysis, it can be seen the influence of knowledge and motivation on the sustainability of MSMEs both directly and through intervening variables of MSMEs performance in penetrating exports. 


\section{Result and Discussion}

\subsection{Supply chain MSMEs products penetrate exports}

All countries have realized how disrupted the supply chain of MSMEs products is during the Covid-19 Pandemic. The majority of MSMEs have difficulty in finding raw materials and marketing their products. Including MSMEs who want to penetrate exports. The circulation of goods in and out of the country is very difficult, because it is limited by the access space. There are so many MSMEs actors who go bankrupt and cannot continue their business. They gave in to various pressures not only from the pandemic but also because the number of sales barriers that were minimal were not worth the production costs. The aspect that needs to be prepared in the era of the COVID-19 pandemic is a form of protection from the government related to the sustainability of MSMEs (Jacobsen, 2020). Many MSMEs have done marketing using e-commerce assistance in order to encourage increased income (Sharifullin et al., 2019) but they still fail due to low market demand (Miraz et al., 2019). Support from the government in the form of abolition of taxes, and various other facilities, including capital assistance that is rolled out every three months through Bank Rakyat Indonesia to MSMEs affected by the Covid-19 pandemic has not been able to ease the burden on MSMEs (Haddouch, Beidouri, \& Oumami, 2019). The cash assistance system for MSMEs has helped their finances (Sari et al. 2019) but because of the heavy pressure, there are still a lot of MSMEs who still give up (Majid, 2019). In order for MSMEs to continue to exist in the face of a pandemic, government assistance is needed, not only material but also in the form of relief from trademark management, marketing permits, and various other policies that favor MSMEs. Considering that MSMEs have so far contributed greatly to local revenue and state revenues, including recruiting workers, reducing unemployment, and as a support for the household economy (Basrowi \& Utami, 2019).

\subsection{Application of the Job Creation Law to Facilitate the Legality of MSMES}

As the main contributor to the Indonesian economy, MSMEs are regulated based on their net worth and profits from sales over a year. The criteria were changed by the so-called Omnibus Law. In this law, the benchmark size is based on working or business capital and the sales results for the past year. In addition, 49 further regulations originate from Law no. 11 of 2020 concerning Job Creation, which came into force on February 2, 2021. Of these 49 regulations, one is Government Regulation no. 7 of 2021 concerning the Ease, Protection, and Empowerment of Cooperatives and Micro, Small, and Medium Enterprises (PP No. 7/2021). Through this government regulation, new criteria were defined for classifying a business as a micro, small, or medium enterprise (MSME). PP 7/2021 also has further provisions in accordance with Article 87 point 1 of the Employment Creation Law, and this changed the MSME criteria from that of Law Number 20 of 2008 concerning Micro, Small, and Medium Enterprises (MSME Law). Before this, the MSME Law used criteria based on net worth and annual sales results, but these were changed through the omnibus law. The criteria for MSMEs, based on Article 35 paragraph 3 of PP 7/2021, are as follows: Micro enterprises have business capital up to 1 billion IDR, excluding land and buildings for business premises. Small businesses, meanwhile, have business capital of between 1 and 5 billion IDR, again excluding land and buildings where the business operates. Finally, medium enterprises have business capital of between 5 and 10 billion IDR, excluding land and buildings for business operations. In the event that business actors pursued business activities prior to the enactment of this government regulation, then the provision of incentives, facilities, protection, and empowerment is extended to micro, small, and medium enterprises that meet the criteria for annual sales set out in Article 35, paragraph (6) of PP 7/2021. These criteria for annual sales state that a business is a micro business if it has annual sales of 0-2 billion IDR. Annual sales of 2-15 billion IDR mean it is a small business, while a medium enterprise has annual sales of 15-50 billion IDR. According to Article 36, Paragraph 1 of PP 7/2021, ministries and institutions can also consider other criteria-such as turnover generated, net worth after taxes and fees, investment value, number of workers employed, incentives and disincentives, local content, and/or the application of environmentally friendly technology — in accordance with the criteria of each business field. The establishment of UMK Companies in Article 154-A of the Omnibus Law states that (1) MSME companies can be established by one person; (2) the establishment of micro and small business companies (as referred to in Paragraph 1) is carried out based on a statement of establishment written in Indonesian; and (3) further provisions regarding the establishment of micro and small business companies are regulated by government regulations for the exemption of legal entity establishment fees. Article 153 I states that (1) micro and small enterprises are granted relief in connection with the establishment of a legal entity and (2) further provisions for the relief of company fees for micro and small enterprises (as referred to in Paragraph 1) are regulated in accordance with laws and regulations in the field of non-tax state revenue. The strength and independence of MSMEs during the pandemic and post-pandemic period need support from the government for continued survival, especially in terms of digitalization, innovation, and commercialization. MSMEs need assistance and facilitation, but such empowerment must seek to develop their independent abilities. MSMEs must advance in the areas of digitalization and intellectual property rights, because they need to commercialize their products with suitable branding and legal protection. Speaking in a webinar titled "Think IP \& SME's: Taking Your Ideas to Market" on April 26, 2021, Indonesian businessman Sandiaga Uno stated that the Indonesia Ministry of Tourism and Creative Economy program aimed to help 8,900 MSMEs register their intellectual property and provide easy access to the creative economy, so these businesses can develop, recover, and thrive. Other programs help in areas like licensing, franchising, co-branding, and transferring 
technology, as well as creating added value. According to Hanung, the Ministry of Cooperatives and MSMEs has stated that it has helped register the IPR of more than 11 thousand MSME products. He adds that the Omnibus Law require that a minimum of $30 \%$ of public facilities, such as rest areas and airports, must be occupied by MSME outlets. This of course needs cooperation between the relevant parties, but on the other hand, MSME products must have a brand registered in order to benefit from this conducive climate. Freddy Haris at the Indonesia ministry of Justice and Human Right stated that the role of regional governments over the last three years has been to protect IPR, and this is especially important for MSMEs and regions. MSMEs' problems with branding are complicated, and this is indicated by Sukmadewi's opinion that brand regulation is not accompanied with a sufficient awareness of trademark registration, especially in MSMEs. There is already a legal awareness of the subject, but this is limited by a lack of attention from the relevant institutions (Sukmadewi, 2018). Vadi (2014) states that there is a relationship between culture and development, and synergy can exist between the protection of cultural resources and sustainable development. MSMEs start with entrepreneurial intentions, usually starting as a small home-based business and slowly growing. When opportunities and policies support them, they have greater potential to develop. To achieve this, a certain social mindset is needed, and according to Lew (2014: 36) this should consider that: "traditional business practices, the unprecedented, accelerating speed of change, high uncertainty and ambiguity, and fear contribute to the anti-social mindset." Thus far, MSME actors have operated and survived for generations within families, but their products have not been properly promoted and protected as the work of indigenous community brands that apply local wisdom. According to Barr (2017:176), "A high performance culture is an output, not an input. Culture is an outcome of, not an input to, organizational performance" and "What we do is what we become". Kotler and Keller (2016:321-322) explain that, "Brands have several functions both for consumers and for companies. The role of the brand to consumers is a promise between companies and consumers". Of course, innovation and marketing strategies must be improved steadily by adopting the latest social media techniques and other methods to promote products. Lew (2014: 47) argues that, "The key thing to remember here is that digital literacy is a skill, and like any skill it can be learned. But it's also a mindset and developing a pro-social approach is entirely in your hands." It is therefore necessary to study strategies to protect and promote MSMEs' local products, so they will be competitive and continue to promote local wisdom. According to Peter and Olson (2010), "The strategy to increase the awareness of MSME actors towards MSME brands and brands on MSME products is very dependent on how well known the brand is". Of course, for this we need awareness of MSME branding and a motivation to pursue it. Handayani, the chairman of MPIG Wedang Uwuh and board member of the Traditional Food and Beverage Association (ASMAMITRA) (March 12, 2021), said that at present, many are selling their products within the pandemic atmosphere of ready-to-eat products, and more creative innovation is needed to survive. Some of them are still trying to penetrate export markets, however, including some small-scale exports to Malaysia, Jeddah, Kuwait, Thailand, Canada, Cambodia, South Korea, and Singapore. Sobirin, the chairman of the Brebes MSME Association and the Central Java MSME Association (20-3-21), hopes that MSMEs will receive various training and export assistance. Indeed, there are one or two MSMEs in the association that have already exported, thus motivating other MSME actors to follow suit.

According to Ries (2014:12), "How to nurture disruptive innovation; internal start up teams require support from senior management to create these structures." Support from superiors for innovation is therefore needed on a top-to-bottom basis. Leland (2016:10), meanwhile, states: "The new branding and marketing mindset and myths, specifically, creative licenses will be taken using various words: such as branding, marketing, promotion and the relationship between products and society." Leland (2016: 11) also argues that, "it is important to understand the need for changes in branding and marketing, given the current digital era. In this case, it is very important to make a leap so that the brand owner is able to increase the strength of SMEs in the market." Producers must change their mindset from that of a traditional entrepreneur to that of a modern one. Indeed, many successful businesses have sprung up without being scattered all over the country, but these must have a mindset that favors innovative and creative products, local wisdom, and technology-based information, especially considering that the digital era has surrounded MSMEs, with big data making this phenomenon even more astonishing. Genduk Priani (March 11, 2021), a producer of various Yogyakarta-style banana chips, still uses production based on local wisdom, with spices and processing methods based on those of previous generations, but some innovation has been made by developing variations. They operate in Jagonalan Lor of the Tirtonirmolo Kasihan Bantul Special Region of Yogyakarta (DIY), and they say that they were allowed to continue working and selling produce as long as they complied with health protocols. Likewise, SMEs that produce ungkep kampong chicken (Ndari Puguh, March 11, 2021) and typical Yogyakarta pecel (Marsih, March 12, 2021) that they sell every Friday at the DIY Agriculture Office want to become more advanced while still promoting their local wisdom as a specialty that gives them a regional advantage. Regarding the role of relevant government intervention, policies and institutions have, of course, been strengthened during the ongoing pandemic. Heri Saptono of the Department of Cooperatives and SMEs, Bantul DIY explained on February 26, 2021, "I am in the Industrial Facilities and Infrastructure Sector taking care of IKM. We carry out the intensive work of making masks and hazmat suits. This is an innovatively characterized product. In the first stage involving 160 tailors, the result was 75,000 batik masks and 1,000 hazmat suits. In the second phase involving 200 tailors, the result was 100,000 batik masks." The labor-intensive work of tailors making masks during the pandemic helped provide jobs, because the COVID-19 taskforce also required masks to be given to volunteers. For these cloth masks, batik was chosen as the material to help batik craftspeople, whose sales had 
fallen by 90 percent during the pandemic. The role of the Yogyakarta Special Region Trade Office (DIY) has so far been to help promote MSME strategies, so that in future, MSMEs can advance their operations and become more successful. The DIY Trade Office's policy has been to provide training that is useful for increasing the export capabilities of MSMEs. The DIY Trade Office also offers a kind of platform for promotional events, for example at the Gabusan Art Market. In summary, the DIY Trade Office helps with marketing strategies and provides training.

\subsection{Innovation and Competitive Advantages for MSME Products}

The head of the ASMAMITRA Yogyakarta association explained in an online interview on February 1, 2021 that MSMEs continued to operate, but they had experienced a 40-50\% decline in turnover. MSMEs with export operations in the Bantul DIY region still exist, such as the producers of organic coconut sugar. Orli, the owner of PT (February 20, 2021), stated that exports had gone smoothly despite the pandemic. Irma, a manager of an MSME in Bantarsari Bogor in West Java (April 2, 2021), stated that at that time, export activities were still in progress due to licensing constraints. Most MSMEs only have Home Industry Food (PIRT). He hopes to be given help and facilitation in all matters relating to MSMEs, so they will not just survive but also be able to compete effectively. Rahmad Bukhari Muslim, the village head of Ciseeng Bogor (March 25, 2021), voiced the aspirations of SMEs in his area and pointed out the challenges posed by the measures imposed by national and local governments during the pandemic, such as social distancing, the application of health protocols, the prohibition of activities with large crowds, greater food security, and vaccination education. The main obstacle during the pandemic is improving the economy again, because a significant number of people have been laid off. When they lose their incomes, their purchasing power inevitably decreases, so many MSMEs lose sales and go out of business. The Khadijah MSME, a producer of fried shallot chili sauce in Brebes in Central Java (online interview 2 February 2021), was currently experiencing declining sales, even though its products had found their way into many outlets in Central Java, having created innovative variants and updated the packaging. Sobirin, the chairman of the Central Java Brebes Association (April 1, 2021), also said that conditions remained relatively smooth but were constrained by a lack of orders resulting in a $40 \%$ drop in turnover. The Indonesian Omnibus law on Job Creation 2020 eased the burden on MSMEs, but studies of product innovation and competitive advantage remain limited. However, "Strategy is a very important step and is closely related to the level of performance in the innovation of a product" (Cooper \& Edgett, 2010:33-40). Another finding in the context of small and medium enterprises is that "SME entrepreneurs are encouraged to always adapt to various external changes in order to face economic changes in the future" (Distanout \& Khongmalai, 2018:1-7). MSMEs must invest in innovation because it can be a strategic tool for gaining a competitive advantage (Aziz and Samad, 2016: 256-266). In this digital era, researchers claim that it is necessary for MSMEs to add value to their products, master innovation, create strong brands, and think globally rather than locally. On the other hand, they need a helping hand in this, and the role of the government is especially important in facilitating licensing, commercialization, increased competitiveness, and legal protection. In this context, innovation has become an important element in developing a competitive advantage, especially when facing heavy competition (Anggadwita \& Mustafid. 2014: 415-423). According to Dereli, "In a competitive environment, organization and management are the keys to success in business" (Dereli, 2015: 1365-70). According to this researcher, once the production factors and business legality are established, management and the business plan are essential to becoming successful. Raymond et al. (2017) stated that, "Sustainability and the ability of a business to survive in a dynamic environment depends on how organizational decisions are made in terms of generating profits without compromising existing resources (employees, society, and the environment)." Coccia (2017:1048-61), meanwhile, posited that, "The fundamental problem in business, especially technology management issues, is how businesses develop innovations and gradually maintain a competitive advantage in the market." In this condition, a businessperson needs to constantly innovate in various ways, including the tools used for production. According to Lynn and Ekgun (1998: 11-18), "Tools used must always be innovated in order to further reduce the cost of electricity, labor, and be able to reduce product defects." In some businesses, innovation can be carried out linearly or non-linearly by anticipating the possibilities of failure and continuously making improvements to avoid such failure through various strategies in order to stay competitive. (Brem et al., 2016: 133-148).

Bandopadhyay and Khan (2020) posit that to increase the export capabilities of MSMEs, the government needs to strengthen fixed investment and financial support. Tripathy and Kumar (2019) also explained the need for support from the government in order to increase the ability of MSMEs to export. Likewise, Michaerl (2015) concluded that support from the government is important when it comes to improving the export performance of MSMEs. Bandopadhyay and Khan (2020) argues that to increase the export capabilities of MSMEs, promotional campaigns must be carried out. Indeed, Ghouse (2014) and Mukherjee (2018) emphasize the use of technology to increase export capability, while Chugan and Singh (2016) point to greater financial support from banks. In a similar vein, Rana and Tiwari (2014) stated that improving the ability of SMEs to export requires a triple helix approach involving the government, industry, and academic institutions. Senthikumar (2015), meanwhile, points to a lack of promotion, such that consumers in export markets are unfamiliar with MSMEs' products. Bahera and Wahi (2017) stated that market pressures abroad also impact the export performance of MSMEs. To improve their export capabilities, MSMEs should increase their innovative capacity (Restrepo-Morales et al., 2019; Hakeem, 2019), so the independence of MSMEs needs to be increased (Zanjurne, 2018) with support from larger companies, so that their 
competitiveness will also improve (Restrepo-Morales et al., 2019). MSMEs are also unable to carry out needs analyses, so their innovation and identification of export opportunities are limited (Khatri, 2019). Until now, MSMEs have struggled to penetrate export marketsdue to a lack of funding from venture capitalists (Chairi et al., 2020), so their products' quality (Hakeem, 2019) and competitiveness remain low (Bhat et al., 2010; Khatri, 2019). In terms of entering export markets, MSMEs continue to encounter various obstacles, especially in obtaining financing (Darsono \& Darwanto, 2019), so they have limited capital available (Hakeem, 2019). Once MSMEs receive support from the government, banks, and other institutions, they will become stronger (Dessai, 2018). SMEs have also failed to export due to limited production capacity, low production-management capabilities, and poor-quality packaging and design (Khatri, 2019). This results in not meeting minimum export quality standards (Jena \& Thatte, 2018). Now, MSME actors are very weak in terms of their knowledge about exporting (Maheswari et al., 2020). MSMEs are also bad at identifying potential buyers (Jena \& Thatte, 2018). The most concerning factor is MSME actors' limited knowledge about domestic export regulations and those in destination countries (Dessai, 2018). MSMEs clearly need support from NGOs, the government, the wider industrial world, and academia (Dessai, 2018). MSMEs also still need to strengthen their use of ICT (Bhat et al., 2020). Synergy must exist between the roles of MSME associations and other stakeholders, such as the SME and Creative Economy Department, regional government, the Trade and Industry Office, and the Agriculture Service, and well as other agencies related to legal matters, such as notaries, The Food and Drug Monitoring Agency (BPOM), the Directorate General in charge of Intellectual Property Rights (Ditjen KI) of the Ministry of Law, and the Human Rights of the Republic of Indonesia. There should also be cooperation with universities and non-governmental organizations (NGOs).

\subsection{Knowledge and motivation of MSME actors for an export orientation}

Table 1 shows the results of the analysis of data collected from a questionnaire that was filled out by MSME actors in three research locations, namely Brebes in Central Java, Yogyakarta, and Bogor.

Table 1

Knowledge of SMEs

\begin{tabular}{|c|c|c|c|c|c|c|c|c|c|c|c|c|}
\hline \multirow[t]{2}{*}{ Score } & \multicolumn{2}{|c|}{ Inst-1 } & \multicolumn{2}{|c|}{ Inst-2 } & \multicolumn{2}{|c|}{ Inst-3 } & \multicolumn{2}{|c|}{ Inst-4 } & \multicolumn{2}{|c|}{ Inst-5 } & \multicolumn{2}{|c|}{ Inst-6 } \\
\hline & Freq. & $\%$ & Freq. & $\%$ & Freq. & $\%$ & Fre. & $\%$ & Fre. & $\%$ & Fre. & $\%$ \\
\hline Really do not understand & 0 & 0 & 4 & 6.3 & 23 & 36.5 & 1 & 1.6 & 1 & 1.6 & 1 & 1.6 \\
\hline Do not understand & 11 & 17.5 & 26 & 41.3 & 29 & 46.0 & 21 & 33.3 & 16 & 25.4 & 8 & 12.6 \\
\hline Understand enough & 18 & 28.6 & 17 & 27.0 & 4 & 6.3 & 23 & 36.5 & 26 & 41.3 & 19 & 30.2 \\
\hline Understand & 25 & 39.7 & 12 & 19.0 & 4 & 6.3 & 12 & 19.0 & 17 & 27.0 & 24 & 38.1 \\
\hline Understand well & 9 & 14.3 & 4 & 6.3 & 3 & 4.8 & 6 & 9.5 & 3 & 4.8 & 11 & 17.5 \\
\hline Total & 63 & 100 & 63 & 100 & 63 & 100 & 63 & 100 & 63 & 100 & 63 & 100 \\
\hline
\end{tabular}

Source: survey 2021

For instrument 1 , the majority of respondents either understood the matter (39.7\%) or understood it very well (14.3\%), while 28.6\% understood enough, and 17.5\% did not understand. Most MSME players therefore understood the difference between registered and well-known brands. For instrument 2, 41.3\% did not understand, $27.0 \%$ understood enough, $19.0 \%$ understood, $6.3 \%$ understood very well, and 6.3\% did not understand very well. Most SME actors therefore do not really understand the various requirements for creating a famous brand. For instrument 3, 46.0\% did not understand, 36.4\% did not understand at all, 6.3\% understood enough, and 4.8\% understood very well. Most of the MSME actors therefore did not yet know the procedures for exporting their products. For instrument 4, 36.5\% of respondents understood enough about how to innovate and digitalize and standard products, $33.3 \%$ did not understand, $19.0 \%$ understood, $9.5 \%$ understood well, and only $1.6 \%$ did not understand at all. For instrument 5,41.3\% understood enough about how to introduce products in an effort to dominate the market, $27.0 \%$ understood, $25.4 \%$ did not understand, $4.8 \%$ understood well, and only $1.6 \%$ were entirely ignorant of strategies for dominating the market with a product. For instrument $6,38.1 \%$ of respondents understood, 30.2\% understood enough, $17.5 \%$ understood well, $12.6 \%$ did not understand, and $1.6 \%$ did not understand at all. It therefore seems that most MSME players already understand to a good degree how to increase the competitiveness of their products in the market.

Table 2

Motivations of MSMEs

\begin{tabular}{|c|c|c|c|c|c|c|c|c|c|c|c|c|c|c|}
\hline \multirow[t]{2}{*}{ Score } & \multicolumn{2}{|c|}{ Inst-7 } & \multicolumn{2}{|c|}{ Inst-8 } & \multicolumn{2}{|c|}{ Inst-9 } & \multicolumn{2}{|c|}{ Inst-10 } & \multicolumn{2}{|c|}{ Inst-11 } & \multicolumn{2}{|c|}{ Inst-12 } & \multicolumn{2}{|c|}{ Inst-13 } \\
\hline & Freq. & $\%$ & Freq. & $\%$ & Freq. & $\%$ & Fre. & $\%$ & Fre. & $\%$ & Fre. & $\%$ & Freq & $\%$ \\
\hline Very unmotivated & 0 & 0 & 0 & 0 & 0 & 0 & 0 & 0 & 0 & 0 & 0 & 0 & 0 & 0 \\
\hline Not motivated & 0 & 0 & 3 & 4.8 & 1 & 1.6 & 0 & 0 & 2 & 3.2 & 0 & 0 & 1 & 1.6 \\
\hline Motivated enough & 4 & 6.3 & 7 & 11.1 & 0 & 0 & 6 & 9.5 & 16 & 25.4 & 6 & 9.5 & 5 & 7.9 \\
\hline Motivated & 17 & 27.0 & 15 & 23.8 & 14 & 22.2 & 19 & 30.2 & 13 & 20.6 & 18 & 28.6 & 17 & 27.0 \\
\hline Very motivated & 42 & 66.7 & 38 & 60.3 & 48 & 76.2 & 38 & 60.3 & 32 & 50.8 & 39 & 61.9 & 40 & 63.5 \\
\hline Total & 63 & 100 & 63 & 100. & 63 & 100 & 63 & 100 & 63 & 100 & 63 & 100.0 & 63 & 100.0 \\
\hline
\end{tabular}

Source: survey 2021

The motivation of MSME actors to become legal entities and get legal protection — such as through business permits, business brands, and halal labeling - is represented by instrument 7. Around two-thirds (66.7\%) of respondents were highly motivated, 
$27.0 \%$ were motivated, and $6.3 \%$ were moderately motivated. All the MSME actors were therefore motivated to some degree to create a registered, well-known brand. For instrument 8 , most respondents $(60.3 \%)$ were highly motivated, $23.8 \%$ were motivated, $11.1 \%$ were motivated enough, and only $4.8 \%$ were not motivated. Most of the MSME actors are therefore strongly motivated to develop products that are suitable for export. For instrument 9, most of the MSME actors (76.2\%) were very motivated to improve product quality, $22.2 \%$ were motivated, and only $1.6 \%$ were pessimistic about having the capacity to improve product quality. For the desire of the MSME actors to carry out intensive branding promotion through the various online media (instrument 10$)$, the majority of the MSME actors $(60.3 \%)$ were very motivated, $30.2 \%$ were motivated, and $9.5 \%$ were moderately motivated. For instrument 11 , just over half of the MSME actors $(50.8 \%)$ were very motivated, $20.6 \%$ were motivated, and $25.4 \%$ were quite motivated to have their own online store and build up into a well-known ecommerce startup, with the remaining $3.2 \%$ being not motivated. For instrument 12 , most respondents $(61.9 \%)$ were highly motivated, $28.6 \%$ were motivated, and $9.5 \%$ were moderately motivated. This basically means that all the business actors wanted to protect the local wisdom of their products to some degree. For the MSMEs' motivation to introduce superior products and become regional icons (instrument 13 ), almost two-thirds of respondents (63.5\%) were very motivated, $27.0 \%$ were motivated, and $7.9 \%$ were only moderately motivated. In addition, a small minority of $1.6 \%$ were not motivated to do so. In response to the research results from both the interviews and questionnaire, training was carried out on a group basis, but considering the conditions during the pandemic, it was only carried out in a limited way through the role of the organization. Following pilot schemes between 2017 and 2021 by the researchers, exports have now begun, albeit on a small scale and limited in terms of destination areas, being mainly confined to Malaysia. Despite some MSMEs still lagging behind, especially with regard to the lack of knowledge for developing a well-known brand and exporting, their motivation to correct this seems very strong. The researchers followed up by creating a suitable empowerment model focused on improving exports by enlightening MSMEs about branding for export-oriented products. This pattern of empowerment certainly accords with the results of the questionnaire and the method of this research, namely by maximizing the role of related stakeholders and increasing the capacity of MSMEs to actively elevate their competencies, innovative capacity, competitiveness, legal protection, and product quality. This will require assistance from stakeholders like the national and local governments, the SME and Cooperatives Service, the Agriculture Service, the Trade and Industry Office, and the Tourism, Communications and Informatics Office, as well as help from law officials, academic researchers, and SME mentors for research and technology.

\subsection{The influence of knowledge and motivation on the sustainability of MSMEs with the intervening variable of Export Performance}

The results of the feasibility of the model can be seen in Table 3 below. 1) Absolute Fit Measures. Based on the results of the suitability of the model, it can be concluded that the resulting model is fit, because it meets the test index based on the required rule of thumb. The size used is based on the type of absolute fit measures as follows. 2) 2 -Chi-Square. The results of this test, a low chi-square $(\chi 2)$ value will result in a significance level greater than 0.05 . The test results obtained a chi-square value of 221,859 which is still above the expected chi-square. 3) CMIN/DF. In this study the model produces a CMIN/DF of 1,541, this value is less than 2 including fit (Ferdinand 2014: 68) so that the model is categorized as acceptable. 4) RMSEA. The results of the RMSEA value of the research model of 0.059 means that the model is accepted properly. 5) GFI. GFI is a non-statistical measure that has a value range between $0-1$. Value $>0.9$ indicates model fit. The GFI value of this research is 0.869 which means that the model is acceptable. (see Table 3 ).

Table 3

Absolute Fit Measures

\begin{tabular}{llll}
\hline Goodness of Fit Index & Cut off value & Estimation & \\
\hline Absolute Fit Measures & & & \\
$\chi^{2}$-Chi-square & 173.00 & 221.859 & Marginal \\
CMIN/DF & $\leq 2.00$ & 1.541 & Fit \\
Probabilities & $\geq 0.05$ & 0.000 & Marginal \\
RMSEA & $\leq 0.08$ & 0.059 & Fit \\
GFI & $\geq 0.90$ & 0.869 & Acceptable \\
\hline
\end{tabular}

\section{Incremental fit Measures}

Incremental fit measures are intended to assess how well the model estimated by the researcher is compared to several alternative models. Some of the sizes used are as follows. 1) AGFI. Recommended AGFI value 0.90. The results showed that the AGFI value of $0.828(>0.8)$ means that the model is acceptable. 2) TLI. The results of this study indicate that the TLI value of $0.962(>0.95)$ means that the model is fit. 3) CFI. The results of this study indicate that the CFI value of $0.968(>$ 0.95 ) means that the model is fit. 4) NFI. In this study, the NFI value of $0.916(>0.9)$ means that the model is acceptable (see Table 4). 
Table 4

Incremental Fit Measures

\begin{tabular}{llll}
\hline Goodness of Fit & Cut off value & Estimation & description \\
\hline Incremental fit Measures & & & \\
AGFI & $\geq 0.90$ & 0.819 & Acceptable \\
TLI & $\geq 0.95$ & 0.962 & Fit \\
CFI & $\geq 0.95$ & 0.968 & Fit \\
NFI & $\geq 0.90$ & 0.916 & Fit \\
\hline
\end{tabular}

Loading Factor Test

Validity criteria with loading factor value with the following conditions: If the loading factor value $>0.7$, then the questionnaire item is valid. If the loading factor value $<0.7$, then the questionnaire item is not valid. After calculating using SmartPLS 3.0 software, the following results are obtained.

Table 5

Validity Test

\begin{tabular}{|c|c|c|c|c|}
\hline No. Item & $\mathrm{X} 1$ & $\mathrm{X} 2$ & $\mathrm{Y}$ & $Z$ \\
\hline $\mathrm{X} 11$ & 0.742 & & & \\
\hline $\mathrm{X} 12$ & 0.819 & & & \\
\hline $\mathrm{X} 13$ & 0.809 & & & \\
\hline X14 & 0.763 & & & \\
\hline $\mathrm{X} 15$ & 0.772 & & & \\
\hline X16 & 0.708 & & & \\
\hline X17 & 0.779 & & & \\
\hline $\mathrm{X} 18$ & 0.779 & & & \\
\hline $\mathrm{X} 21$ & & 0.731 & & \\
\hline $\mathrm{X} 22$ & & 0.771 & & \\
\hline $\mathrm{X} 23$ & & 0.726 & & \\
\hline X24 & & 0.777 & & \\
\hline $\mathrm{X} 25$ & & 0.741 & & \\
\hline $\mathrm{X} 26$ & & 0.732 & & \\
\hline $\mathrm{X} 27$ & & 0.782 & & \\
\hline X28 & & 0.832 & & \\
\hline Y1 & & & 0.849 & \\
\hline Y10 & & & 0.825 & \\
\hline Y11 & & & 0.871 & \\
\hline Y12 & & & 0.779 & \\
\hline Y2 & & & 0.957 & \\
\hline Y3 & & & 0.876 & \\
\hline Y4 & & & 0.872 & \\
\hline Y5 & & & 0.811 & \\
\hline Y6 & & & 0.869 & \\
\hline Y7 & & & 0.737 & \\
\hline Y8 & & & 0.741 & \\
\hline Y9 & & & 0.856 & \\
\hline $\mathrm{Z1}$ & & & & 0.811 \\
\hline $\mathrm{Z} 2$ & & & & 0.795 \\
\hline $\mathrm{Z3}$ & & & & 0.740 \\
\hline Z4 & & & & 0.734 \\
\hline $\mathrm{Z5}$ & & & & 0.833 \\
\hline Z6 & & & & 0.763 \\
\hline $\mathrm{Z7}$ & & & & 0.750 \\
\hline Z8 & & & & 0.753 \\
\hline
\end{tabular}

From the results of the loading factor above, it can be seen that all questionnaire items have a value of more than 0.7 which means that all indicators are valid

\section{Reliability Test}

The decision criteria for reliability testing with composite reliability are provided: if the composite reliability value is $>0.7$, then the questionnaire item is reliable, and if the composite reliability value is $<0.7$, then the questionnaire item is not reliable. The following is the result of the calculation of composite reliability. 
Table 6

Composite Reliability

\begin{tabular}{lcccc}
\hline & Cronbach's Alpha & rho_A & Composite Reliability & Average Variance Extracted (AVE) \\
\hline X1 & 0.903 & 0.904 & 0.922 & 0.596 \\
X2 & 0.897 & 0.898 & 0.917 & 0.581 \\
Y & 0.961 & 0.964 & 0.966 & 0.704 \\
Z & 0.903 & 0.906 & 0.922 & 0.598 \\
\hline
\end{tabular}

From the results of composite reliability as shown in the table above, all composite reliability values in each construct have a value greater than 0.7 , which means that all constructs are reliable.

\section{Effect of Endogenous and Exogenous Variables}

Fig.1 explains the effect of endogenous and exogenous variables, as well as to see the direct and indirect effects based on the model.

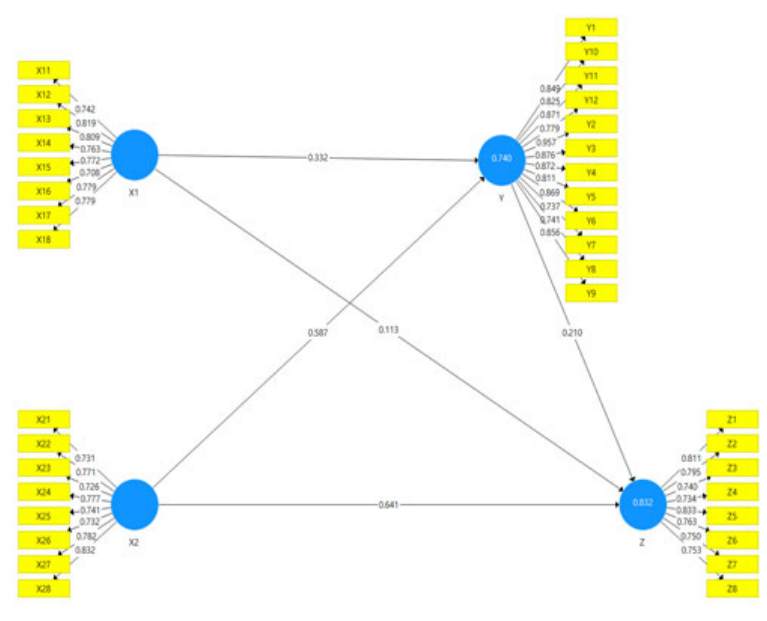

Fig. 1. Structural Test Model (Hypothesis)

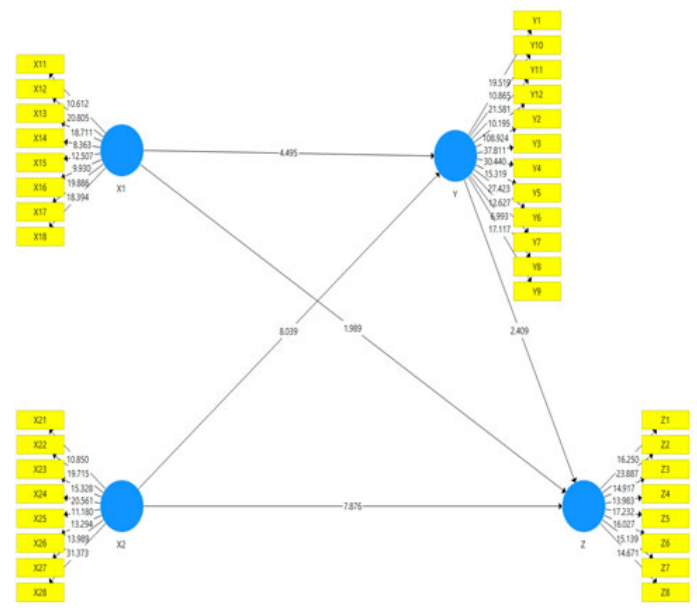

Fig. 2. Model significance test

Hypothesis testing is carried out based on the results of the Inner Model (structural model) test which includes r-square output, parameter coefficients and t-statistics. To see whether a hypothesis can be accepted or rejected, among others, by paying attention to the significance value between constructs, t-statistics, and p-values. The hypothesis testing of this research was carried out with the help of the SmartPLS (Partial Least Square) 3.0 software. These values can be seen from the bootstrapping results. The rule of thumb used in this study is t-statistic $>1.96$ with a significance level of $p$-value 0.05 $(5 \%)$ and a positive beta coefficient. The value of testing the hypothesis of this research can be shown in the table and the results of this research model can be described as shown in Fig 2. Hypothesis testing is carried out on all samples that have been obtained from the questionnaire. Hypothesis testing is done using SmartPLS 3.0 software and the results are as follows.

Table 7

Hypothesis Testing $\left(\mathrm{H}_{1}-\mathrm{H}_{5}\right)$

\begin{tabular}{|c|c|c|c|c|c|}
\hline & Original Sample (O) & Sample Mean (M) & Standard Deviation (STDEV) & T Statistics (|O/STDEV $\mid)$ & P Values \\
\hline $\mathrm{X} 1 \rightarrow \mathrm{Y}$ & 0.332 & 0.333 & 0.074 & 4.495 & 0.000 \\
\hline $\mathbf{X} 1 \rightarrow \mathrm{Z}$ & 0.113 & 0.116 & 0.057 & 1.989 & 0.047 \\
\hline $\mathbf{X} 2 \rightarrow \mathrm{Y}$ & 0.587 & 0.589 & 0.073 & 8.039 & 0.000 \\
\hline $\mathbf{X} 2 \rightarrow \mathbf{Z}$ & 0.641 & 0.642 & 0.081 & 7.876 & 0.000 \\
\hline $\mathbf{Y} \rightarrow \mathbf{Z}$ & 0.210 & 0.209 & 0.087 & 2.409 & 0.016 \\
\hline
\end{tabular}

Source: Results of data analysis with Smart-PLS3.0

\section{$\mathbf{H}_{1}$ : Knowledge influences the export performance of MSMEs.}

From the results of data analysis with Smart-PLS, it is stated that the t-statistic is significant. because $>1.96$ with p-value $<0.05$, so hypothesis 1 is accepted. Knowledge influences the export performance of MSMEs in Indonesia. The higher the knowledge of MSME actors, the higher the performance of MSME Exports in Indonesia. When it comes to export performance, the aspect that needs to be improved is the knowledge of MSME actors.

$\mathbf{H}_{2}$ : Motivation influences the export performance of MSMEs. 
From the results of the analysis, it is stated that the t-statistic is significant. because $>1.96$ with p-value $<0.05$, so hypothesis 2 is accepted. Motivation influences the export performance of MSMEs in Indonesia. The higher the motivation of MSME actors, the higher the export performance of MSMEs in Indonesia. To improve the performance of MSMEs, it can be done by increasing the motivation of MSME actors.

\section{H3: Knowledge influences the sustainability of MSMEs.}

From the results of data analysis, it is stated that the t-statistic is significant. because $>1.96$ with p-value $<0.05$, so the hypothesis is accepted. Knowledge has an effect on the sustainability of MSMEs in Indonesia. The higher the knowledge of MSME actors, the higher the chance for MSME sustainability. To improve the sustainability of MSMEs, the aspect that needs to be improved is the knowledge of MSME actors.

\section{$\mathbf{H}_{4}$ : Motivation influences the sustainability of MSMEs.}

From the results of data analysis, it is stated that the t-statistic is significant. because $>1.96$ with p-value $<0.05$, so the hypothesis is accepted. Motivation affects the sustainability of MSMEs in Indonesia. The higher the motivation of MSME actors, the higher the level of MSME sustainability.

\section{H5: Export performance influences the sustainability of MSMEs.}

From the results of data analysis, it is stated that the t-statistic is significant. because $>1.96$ with p-value $<0.05$, so the hypothesis is accepted. Export performance affects the sustainability of MSMEs in Indonesia. The higher the ability of MSMEs to export products, the higher the chances of MSME sustainability.

Table 8

Hypothesis Testing $\left(\mathrm{H}_{6}-\mathrm{H}_{7}\right)$

\begin{tabular}{|c|c|c|c|c|c|}
\hline & Original Sample (O) & Sample Mean (M) & Standard Deviation (STDEV) & T Statistics (|O/STDEV $\mid)$ & P Values \\
\hline $\mathbf{X} 1 \rightarrow \mathbf{Y} \rightarrow \mathbf{Z}$ & 0.069 & 0.068 & 0.030 & 2.297 & 0.022 \\
\hline $\mathbf{X} \mathbf{2} \rightarrow \mathbf{Y} \rightarrow \mathbf{Z}$ & 0.123 & 0.124 & 0.058 & 2.129 & 0.034 \\
\hline
\end{tabular}

Source: Results of data analysis with Smart-PLS3.0

H6: Knowledge influences sustainability with export performance as an intervening variable.

From the results of data analysis, it is stated that the t-statistic is significant. because $>1.96$ with p-value $<0.05$, so the sixth hypothesis is accepted. There is an influence of knowledge on sustainability through the intervening variable of MSME export performance in Indonesia. To improve the sustainability of MSMEs, it can be done directly by increasing knowledge or through MSME export performance. Knowledge has a direct influence on sustainability that is greater than through the export performance of MSMEs.

\section{$\mathbf{H}_{7}$ : Motivation influences sustainability with export performance as an intervening variable.}

From the results of data analysis, it is stated that the t-statistic is significant. because $>1.96$ with p-value $<0.05$, so the seventh hypothesis is accepted. Motivation has an indirect influence on sustainability through the export performance of MSMEs. To improve the sustainability of MSMEs, it can be done directly by increasing the motivation of MSME actors and through MSME export performance. Motivation has a direct influence on sustainability, which is greater than through the export performance of MSMEs.

\section{Conclusion}

The supply chain of MSME products in order to penetrate exports is very important, but MSME actors have not been able to meet all export requirements. MSMEs must be able to meet all export requirements to create a balanced supply chain. The level of knowledge for exporting products is still low among MSMEs, and they need to gain value through digitalization, standardization and established IPR. The motivation to do this is huge, however, so they need to be educated about these subjects through training and mentoring, not just for establishing a legal entity and certifying products but also improving their competitiveness in the market. For MSMEs to develop innovative, well-designed products for export as a legal entity with legal product ownership and promote them through digital technologies, it is necessary to implement an empowerment model that engages MSME organizations with stakeholders like the SME Cooperative Service and Tourism and Creative Economy Office, regional government, the Trade and Industry Office, Agriculture, the Director General of Intellectual Property, public notaries, and the Ministry of Law and Human Rights in order to promote local wisdom and uniqueness, because every region has an innate creativity that deserves to be branded and exported. Based on the results of quantitative analysis using the SEM approach and smart PLS software, it can be concluded that the influence between the level of knowledge possessed by MSMEs actors and the motivation of MSMEs actors in operating MSMEs on the sustainability of MSMEs, either directly or indirectly through the intervening variable of MSMEs performance in penetrating exports. 


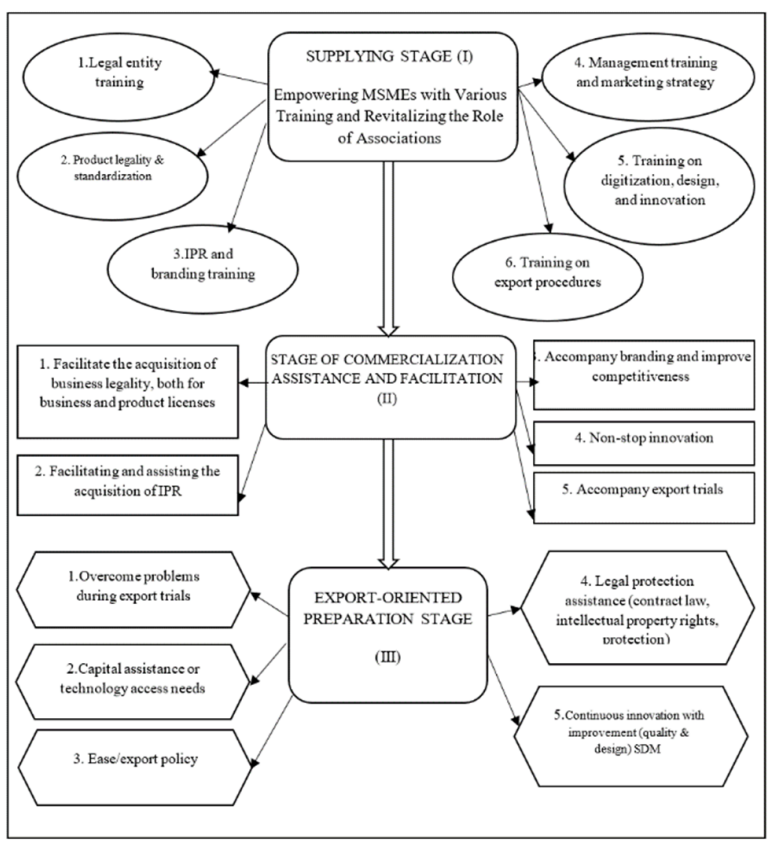

Fig. 3. The conceptual model

\section{Acknowledgment}

We express thanks to the Indonesia Ministry of Research and Technology for funding this research and for the good cooperation from YARSI, a connected institution, and the research subject official.

\section{References}

Anggadwita, G., \& Mustafid, Q. Y. (2014). Identification of factors influencing the performance of small medium enterprises (SMEs). Procedia-Social and Behavioral Sciences, 115, 415-423. https://doi.org/10.1016/j.sbspro.2014.02.448.

Abd Aziz, N. N., \& Samad, S. (2016). Innovation and competitive advantage: Moderating effects of firm age in foods manufacturing SMEs in Malaysia. Procedia Economics and Finance, 35, 256-266. https://doi.org/10.1016/s22125671(16)00032-0.

Bandopadhyay, K., \& Khan, T. L. (2020). Factors of Export Promotion of MSME in India with Special Reference to Raw Material Availability. SEDME (Small Enterprises Development, Management \& Extension Journal), 47(1), 17-32. https://doi.org/10.1177/0970846420930446

Barr, S. (2017). Prove it!: How to create a high-performance culture and measurable success. New Jersey: John Wiley \& Sons. Hoboken.

Basrowi., \& Utami, Pertiwi. (2020). Building Strategic Planning Models Based on Digital Technology in the Sharia Capital Market. J. Advanced Res. L. \& Econ., 11, 747. http://journals.aserspublishing.eu/jarle/index

Basrowi., Utami, P., Ali, J., \& Salleh, M. S. (2021). Supply Chains In Indonesia Facing Virus Corona (COVID-19): Models Innovation And Obstacles Faced. Bina Bangsa International Journal Of Business And Management, 1(1), 112.https://doi.org/10.46306/bbijbm.v1i1.1

Behera, H., Wahi, G. (2017). How have MSME sector credit and exports fared? (Mint Street Memo No. 13), 18. https://rbidocs.rbi.org.in/rdocs/MintStreetMemos/13MSMN17082018.pdf

Behera, H., \& Wahi, G. (2018). How have MSME sector credit and exports fared. Mint Street Memos (Mint Street Memo No. 13), 1-8. https://rbidocs.rbi.org.in/rdocs/MintStreetMemos/13MSMN17082018.pdf

Bhat, S., Gijo, E.V., Rego, A.M. and Bhat, V.S. (2021). Lean Six Sigma competitiveness for micro, small and medium enterprises (MSME): an action research in the Indian context. The TQM Journal, 33(2), 379-406. https://doi.org/10.1108/TQM-04-2020-0079

Brem, A., Maier, M., \& Wimschneider, C. (2016). Competitive advantage through innovation: the case of Nespresso. European Journal of Innovation Management, 19(1), https://doi.org/10.1108/EJIM-05-2014-0055pp. 133148

Chairi, Z., Afrita, M., \& Yudhistira, E. (2020). The System of Partnership Conducted by the Venture Capital Company As the Alternative Funding for the MSME in Medan (Study Case in Pt. Sarana Sumut Ventura Medan). International Journal 
of Management (IJM), 11(3), 208-219. https://doi.org/10.34218/IJM.11.3.2020.022

Chugan, P. K., \& Singh, S. (2016). Impact of Type of Export Finance on Firms' Export Profitability: A Study of Industrial Clusters in Gujarat, India. Exceeding The Vision: Innovate, Integrate and Motivate"(Eds.) N. Delener, Leonora Fuxman, F. Victor Lu, and Susana Rodrigues, Global Business and Technology Association (GBATA), NY, USA, 8996. https://openlearning.aauekpoma.edu.ng/Uploads/Journals/ict-innovation-into-teaching-of-business-education-innigerian-universities-pg-400-406.pdf

Coccia, M. (2017). Sources of technological innovation: Radical and incremental innovation problem-driven to support competitive advantage of firms. Technology Analysis \& Strategic Management, 29(9), 1048-1061. https://doi.org/10.1080/09537325.2016.1268682.

Cooper, R. G., \& Edgett, S. J. (2010). Developing a product innovation and technology strategy for your business. ResearchTechnology Management, 53(3), 33-40. https://doi.org/10.1080/08956308.2010.11657629.

Darsono, D., \& Darwanto, D. (2019). Strengthening the MSME Through Institutional Cooperation Improvement Between MSME and Sharia Microfinance Institutions (SMFI). Jurnal Ilmiah Al-Syir'ah, 17(1), 65-76. https://doi.org/10.30984/jis.v17i1.809

Dhar, S. K. (2014). Micro Small and Medium Enterprises (MSMEs) in India: Its scopes and challenges [Unpublished conference proceedings]. https://ssrn.com/abstract=2541162 as on 10.11 .2019

Dereli, D. D. (2015). Innovation management in global competition and competitive advantage. Procedia-Social and behavioral sciences, 195, 1365-1370.. https://doi.org/10.1016/j.sbspro.2015.06.323.

Distanont, A., \& Khongmalai, O. (2020). The role of innovation in creating a competitive advantage. Kasetsart Journal of Social Sciences, 41(1), 15-21. https://doi.org/10.1016/j.kjss.2018.07.009.

Ghouse, G. S. (2014). Export competitiveness of India: The role of MSMEs to play. International Journal of Management Research \& Review, 4(11), 1069-1084.

Ghouse, S. M. (2014). Export Competitiveness of India: The Role of MSME^ ${ }^{\wedge}$ sup $\mathrm{S}^{\wedge} \mathrm{TO}$ PLAY!. International Journal of Management Research and Reviews, 4(11), 1069-1084.

Haddouch, H., Beidouri, Z., \& El Oumami, M. (2019). Supply chain management: A review of approaches, practices and impact on performance. International Journal of Supply Chain Management, 8(6), 1-13.

Hakeem, M.M. (2019). Innovative solutions to tap "Micro, Small and Medium Enterprises" (MSME) market: A way forward for Islamic banks. Islamic Economic Studies, 27(1), 38-52. https://doi.org/10.1108/IES-05-2019-0002.

Hopman, J., Allegranzi, B., \& Mehtar, S. (2020). Managing COVID-19 in low-and middle-income countries. Jama, 323(16), $1549-1550$.

Ivanov, D. (2020). Predicting the impacts of epidemic outbreaks on global supply chains: A simulation-based analysis on the coronavirus outbreak (COVID-19/SARS-CoV-2) case. Transportation Research Part E: Logistics and Transportation Review, 136, 101922.

Jacobsen, K. H. (2020). Will COVID-19 generate global preparedness?. Lancet (London, England), $395(10229), 1013$.

Jena, N. R., Thatte, L. R., \& Ket, V. G. (2018). Performance of the micro, small and medium enterprises (MSMEs) manufacturing sector in select states in India: The concept of MSME Manufacturing Business Facilitator (MSME-MBF) Index. Academy of Entrepreneurship Journal, 24(1), 1-22.

Khatri, P. (2019). A Study of the Challenges of the Indian MSME Sector. IOSR Journal of Business and Management, 21(2), 05-13.

Kotler, P., Keller, K. L., Manceau, D., \& Dubois, B. (2016). Marketing Management, 15e édition. New Jersy: Pearson Education.

Kozlenkova, I. V., Hult, G. T. M., Lund, D. J., Mena, J. A., \& Kekec, P. (2015). The role of marketing channels in supply chain management. Journal of Retailing, 91(4), 586-609.doi:10.1016/j.jretai.2015.03.003

Lee, V. J., Aguilera, X., Heymann, D., Wilder-Smith, A., Lee, V. J., Heymann, D. L., ... \& Yeo, W. Q. (2020). Preparedness for emerging epidemic threats: a Lancet Infectious Diseases Commission. The Lancet Infectious Diseases, 20(1), 17-19.

Leland, K. (2016). The brand mapping strategy: Design, build, and accelerate your brand. USA: Entrepreneur Press.

Lew, D.K. (2014). The social executive, McDougall. Australia: John Wiley Sons.

Lynn, G. S., \& Akgün, A. E. (1998). Innovation strategies under uncertainty: a contingency approach for new product development. Engineering Management Journal, 10(3), 11-18. https://doi.org/10.1080/10429247.1998.11414991.

MacLaren, G., Fisher, D., \& Brodie, D. (2020). Preparing for the most critically ill patients with COVID-19: the potential role of extracorporeal membrane oxygenation. Jama, 323(13), 1245-1246.doi:10.1001/jama.2020.2342

Maheshwari, M., Samal, A., \& Bhamoriya, V. (2020). Role of employee relations and HRM in driving commitment to sustainability in MSME firms. International Journal of Productivity and Performance Management. https://doi.org/10.1108/IJPPM-12-2019-0599

Majid, Z. A., Kamarulzaman, N. H., Rahman, A. A., Jaafar, H. S., Rahman, N. A. A., \& Mohammad, M. F. (2019). Halal Integrity from Logistics Service Provider Perspective. International Journal of Supply Chain Management, 8(5), 1-9.

Marlinah, L. (2020). Peluang dan Tantangan UMKM Dalam Upaya Memperkuat Perekonomian Nasional Tahun 2020 Ditengah Pandemi Covid 19. Jurnal Ekonomi, 22(2), 118-124.

Miraz, M. H., Hye, A. M., \& Habib, M. M. (2019). The impact of Blockchain-bitcoin in Malaysian markets. International Journal of Supply Chain Management, 8(5), 136.

Mukherjee, S. (2018). Challenges to Indian micro small scale and medium enterprises in the era of globalization. Journal of Global Entrepreneurship Research, 8(1), 1-19. 
Nuzzo, J., Mullen, L., Snyder, M., Cicero, A., \& Inglesby, T. V. (2019). Preparedness for a high-impact respiratory pathogen pandemic. Baltimore, MD, USA: Johns Hopkins Center for Health Security.

Noe, R. A., Hollenbeck, J. R., Gerhart, B., \& Wright, P. M. (2017). Human resource management: Gaining a competitive advantage. New York, NY: McGraw-Hill Education.

Rana, A., \& Tiwari, R. (2014). MSME sector: Challenges and potential growth strategies. International Journal of Entrepreneurship \& Business Environment Perspectives, 3(4), 1428-1432.

Restrepo-Morales, J.A., Loaiza, O.L., \& Vanegas, J.G. (2019). Determinants of innovation: A multivariate analysis in Colombian micro, small and medium-sized enterprises. Journal of Economics, Finance and Administrative Science, 24(47), 97-112. https://doi.org/10.1108/JEFAS-09-2018-0095.

Reis, E. (2011). The lean startup. New York: Crown Business, 27.

Sari, N. Z. M., Azhar, S., Afiah, N. N., Sueb, M., \& Suharman, H. (2019). Supply Chain Quality Accounting Information System With Business Strategy Effective In BUMN Bandung Indonesia. International Journal Of Supply Chain Management (IJSCM), 81-86.

Sawant Dessai, D. (2016). MSME and role of Government in MSME development. MSME and Role of Government in MSME Development (October 10, 2016). https://doi.org/10.2139/ssrn.3072996

Senthilkumar, R. (2015). Problems and prospects of coir industry. Asia Pacific Journal of Research, 1(34), 201-204

Sharifullin, A.G., Safina, G.R., Fedorov, V.A., \& Kurzhanova, A.A. (2019). Digital Economy for the Supply Chain as Indicator of Competitiveness of the Cites. International Journal of Supply Chain Management, 8(5), 249-252

Sukmadewi, Y. D. (2018). Kajian Legalitas Dan Manajemen Merek Pada UMKM Munaku Sulam Pita Semarang. Law Reform, 14(2), 275-290.

Taufik, A. I. (2017). Evaluasi Regulasi Dalam Menciptakan Kemudahan Berusaha Bagi UMKM. Jurnal Rechts Vinding: Media Pembinaan Hukum Nasional, 6(3), 369-386.

Tripathy, I. G., \& Kumar, P. (2019). Challenges of Indian MSME Exporters: A Review. SEDME (Small Enterprises Development, Management \& Extension Journal), 46(3), 189-195.

Vadi, V. (2014). Cultural heritage in international investment law and arbitration. United Kingdom: Cambridge University Press.

Zanjurne, P. (2018). Growth and Future Prospects of MSME in India. International Journal of Advanced Engineering, Management and Science, 4(8), 264315. https://doi.org/10.22161/ijaems.4.8.5 


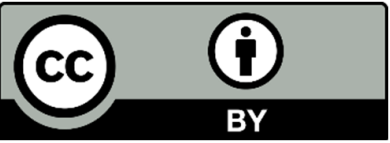

(C) 2022 by the authors; licensee Growing Science, Canada. This is an open access article distributed under the terms and conditions of the Creative Commons Attribution (CCBY) license (http://creativecommons.org/licenses/by/4.0/). 